Unlocking innovation potential: A typology of family business innovation postures and the critical role of the family system

\title{
Emanuela Rondi
}

Free University of Bozen-Bolzano and Lancaster University

Faculty of Economics and Management

Universitätsplatz 1 - Piazza Università, 1 39100 Bozen-Bolzano

E-mail: emanuela.rondi@unibz.it

\section{Alfredo De Massis ${ }^{\mathrm{a}}$}

Free University of Bozen-Bolzano and Lancaster University

Faculty of Economics and Management

Universitätsplatz 1 - Piazza Università, 1

39100 Bozen-Bolzano

Phone: +390471 013303

E-mail: a.demassis@lancaster.ac.uk

and

Department of Entrepreneurship, Strategy \& Innovation, Lancaster University Management School (UK)

\section{Josip Kotlar}

Lancaster University

Centre for Family Business,

Department of Entrepreneurship, Strategy \& Innovation,

Bailrigg, Lancaster (UK), LA1 4YX

E-mail: j.kotlar@lancaster.ac.uk

Formatted: Italian (Italy)

Formatted: Italian (Italy)

Formatted: Italian (Italy)

Keywords: Innovation posture, goal diversity, family cohesion, family business, innovation, paradox.

${ }^{\text {a }}$ Corresponding author

** CONFIDENTIAL AND NOT TO BE SHARED WITHOUT WRITTEN PERMISSION **

** ACCEPTED FOR PUBLICATION IN JOURNAL OF FAMILY BUSINESS STRATEGY ** 


\title{
Unlocking innovation potential: A typology of family business innovation postures and the critical role of the family system
}

\begin{abstract}
How can family firms unlock their innovation potential? Despite the recent growth in research on family business innovation, existing literature has yielded controversial findings. Family firms are recognized as more conservative and steadfast to their tradition, however many of the most innovative firms worldwide are family businesses. This points to an apparent willingnessability paradox in family business innovation. Drawing on family business innovation and family systems literature, we argue that family characteristics are an important yet overlooked driver of this paradoxical tension. We develop the construct of family business innovation posture, and identify a typology of four ideal types: Seasoner, Re-enactor, Digger, and Adventurer. Furthermore, we explore and illustrate with empirical data the necessary fit between family business innovation posture and family-related dimensions to resolve the willingness-ability paradox. The article examines the implications of the typology for family business innovation research by exploring the effects of intra-family succession, outlining important directions for future research aimed at advancing current understanding of the role of the family in family business innovation, and providing practical insights for family business owners, managers, and consultants.
\end{abstract}

Keywords: Innovation posture, family systems, tradition, family business, innovation, paradox, typology 


\section{Introduction}

Family firms are often stigmatized as conservative and steadfast to their tradition for generations yet represent a large portion of the world's most innovative firms (Kammerlander \& Van Essen, 2017). Innovation is widely acknowledged as a key driver of growth for organizations and economies (Garud, Tuertscher, \& Van de Ven, 2013). Moreover, a growing body of research emphasizes the importance of innovation for the long-term sustainability of family firms (e.g. De Massis, Frattini, \& Lichtenthaler, 2013; Röd, 2016; Urbinati, Franzò, De Massis, \& Frattini, 2017). These studies collectively show remarkable differences in innovation between family and non-family business. For example, compared to non-family firms, family firms may take longer to decide whether to implement a discontinuous technology, but once they decide, do so quicker (König, Kammerlander, \& Enders, 2013). Likewise, research shows that risk-aversion, parsimony, wealth concentration, and higher decision-making power lead family businesses to invest fewer resources in innovation compared to non-family firms, but at the same time, are more efficient in transforming these inputs into innovative outputs, especially when the family not only owns but also leads the company (Duran, Kammerlander, Van Essen, \& Zellweger, 2016), suggesting a strong imprinting effect of the family on innovation.

Although research shows that family businesses innovate differently from non-family firms, researchers are still puzzled by the sources of this difference. In a recent study, Chrisman, Chua, De Massis, Frattini, and Wright (2015) argue that family firms innovate less despite being more able to do so, pointing to a "willingness-ability paradox" in family business innovation. Family businesses need to understand how to resolve this innovation paradox to unlock their potential. Unfortunately, family business innovation research has so far focused largely on the firm side, thereby overlooking the important and heterogeneous effects of the family on family business innovation (De Massis, Di Minin, \& Frattini, 2015). Recently, several calls have been made to further integrate family systems theory and family-related dimensions to explain family 
firms' distinctive innovative behaviors and unveil the underlying mechanisms (Jaskiewicz \& Dyer, 2017; Jaskiewicz, Combs, Shanine, \& Kacmar, 2017). To address this gap and provide new insights on the role of the family in family business innovation, our study addresses the following research question: What is the role of the family system in helping the family firm resolve the willingness-ability paradox and unlock its innovation potential?

We focus on the construct of family firm innovation posture, defined as the strategic orientation the owning family imprints on the family business, shaping the firm's innovation climate, philosophy, and practices. By examining the variety of family business innovation postures in relation to different levels of risk-taking propensity and attachment to tradition, we develop a typology of four ideal types: Seasoner, Re-Enactor, Digger, and Adventurer. By integrating this typology with family systems theory, we argue that attaining a fit between the family business innovation posture and the family-related dimensions can help family firms resolve the willingness-ability paradox and enable their innovation potential. Specifically, we focus our analysis on two family-related dimensions: family cohesion and family goal diversity. Family cohesion stems from "emotional bonding that family members have towards one another" (Olson, 2000: 145). Family goal diversity instead refers to "the width of the range of organizational goals actively pursued by members of a family business" (Kotlar \& De Massis, 2013: 1274). Building on our theorization and empirical evidence obtained from family business consultants and illustrative examples, we identify the ideal configurations of risktaking propensity, tradition attachment, family cohesion, and family goal diversity that are most likely to enable family firms to address the willingness-ability paradox. Finally, our analysis highlights the opportunity that intra-family succession offers to modify these dimensions and unlock their innovation potential.

This study makes three main contributions. First, by introducing the new family business innovation posture construct and developing the related typology, we contribute to innovation 
literature by identifying four equifinal family business orientations toward innovation in relation to two important but thus far disjointed dimensions in family business innovation literature: risk-taking propensity and tradition attachment. In so doing, we extend existing research on family business innovation by clarifying family firms' heterogeneous orientations toward innovation, taking into account the role of the family. Second, we address recent calls to examine family systems for an enhanced understanding of family business behavior. Specifically, we delve deeper into the family heterogeneity dimensions and provide new insights on the influence of two key family-related dimensions (family goal diversity and family cohesion) on family business innovation. Third, our analysis identifies conditions of fit between the family system and the family business innovation posture, and clarifies the role of familyrelated mechanisms to resolve the aforementioned willingness-ability paradox with crucial insights to reconcile and better interpret the conflicting findings of prior research.

In the next section, we provide an overview of research on family business innovation, pointing out crucial aspects that deserve further attention. This is followed by a brief description of our methodological approach. We then introduce our construct and typology of family business innovation posture. Thereafter, we explore the family-related dimensions of cohesion and goal diversity, and examine the necessary fit between the family business innovation posture and family-related dimensions to resolve the willingness-ability paradox. We discuss the calibration effect that succession can play in unlocking the family business innovation potential. Finally, we outline the study's implications, limitations, and future research directions.

\section{Innovation in family business}

Innovation, defined as the set of activities through which a firm conceives, designs, manufactures, and introduces new products, services, processes, or business models (Freeman, 
1976), is key driver of competitive advantage and superior firm performance (Blundell, Griffiths, \& Van Reenen, 1999; Calantone, Chan, \& Cui, 2006). Although innovation is arguably critical for family firms to renew their competitive advantage and sustain performance over the long run, family businesses are often portrayed as conservative and reluctant to innovate (Duran et al., 2016), as well as more path-dependent than non-family firms (Economist, 2009). However, these views are in contrast with the fact that over $50 \%$ of the most innovative firms in Europe are controlled by families (Forbes, 2014). Due to this ambiguous empirical evidence, scholars have paid increasing attention to understanding the reasons for this controversy, clarifying the links between innovation inputs and outputs in family firms, and explaining the impact of family involvement on innovation activities (see De Massis et al. (2013) and Röd (2016) for recent systematic reviews).

The long-term orientation of family owners would suggest they have a greater incentive to invest more resources in innovation, yet the findings indicate that due to risk aversion and potentially higher agency costs that lead to inner family conflicts, they invest less in research and development (e.g. Chrisman \& Patel, 2012; Gomez-Mejia, Campbell, Martin, Hoskisson, Makri, \& Sirmon, 2014). However, family firms can be more efficient in converting innovation inputs into innovation outputs, sometimes leading to even higher innovation outputs than nonfamily firms (Duran et al., 2016). Researchers propose and provide evidence that family firms invest less in innovation but perform better, or innovate more with less (Duran et al., 2016; De Massis, Audretsch, Uhlaner, \& Kammerlander, 2018). Therefore, focusing only on either the innovation inputs or outputs prevents a fine-grained understanding of family business innovation and particularly the unique innovative behavior of family firms (Patel \& Chrisman, 2014).

For these reasons, growing research attention has been dedicated to innovation activities, insofar as showing that family firms benefit from more flexible structures and decision-making 
(Craig \& Dibrell. 2006; De Massis, Kotlar, Frattini, Chrisman \& Nordqvist, 2016), less formalized processes (De Massis, Frattini, Pizzurno \& Cassia, 2015), implementing idiosyncratic resource bundling processes (Carnes \& Ireland, 2013), and rarely relying on external collaborations (Kotlar, De Massis, Frattini, Bianchi, \& Fang, 2013; Nieto, Santamaria, \& Fernandez, 2015). Examining discontinuous technology adoption, König et al. (2013) suggest that control goals and intra-family succession create greater challenges for family firms in relation to embracing the risk of adopting a discontinuous technology. However, once family firms overcome such barriers, they also benefit from faster adoption with greater flexibility, stamina, and investments over long periods of time (König et al., 2013).

In sum, prior research shows that innovation in the context of family business occurs in a different and distinctive way. However, literature thus far mainly focuses on the business side of the family firm, overlooking the role of the family system in family business innovation.

\section{The willingness-ability paradox in family business innovation}

Family business innovation literature has primarily examined firm-level drivers of innovation, whereas the role of the family system has only been scarcely investigated. This, in turn, has limited our current understanding of how family aspects may affect the family-oriented particularistic behavior of family firms (De Massis, Kotlar, Chua, \& Chrisman, 2014). Two necessary but individually insufficient conditions are required for family-oriented particularistic behavior: ability and willingness (De Massis et al., 2014). Ability is defined as "the discretion of the family to direct, allocate, add to or dispose of a firm's resources" (De Massis et al., 2014: 6), and emerges from family involvement in the firm's ownership, governance and management, including latitude in choosing from among a range of structural, strategic, and tactical options. Willingness is the "favorable disposition of the involved family 
to engage in distinctive behavior" (De Massis et al., 2014: 347), and drives the owner to lead the firm in a distinctive direction that reflects the family's goals.

Stemming from these sufficiency conditions, scholars suggest that innovation in family business is characterized by the "willingness-ability paradox" whereby family firms are less inclined to innovate (willingness) although they could (ability) innovate more than their nonfamily counterparts (Chrisman et al., 2015a; De Massis et al., 2014). Their higher ability to innovate is shaped by their long-term orientation, tacit knowledge, and long-term leader tenure (Röd, 2016). The reasons for their lower willingness to innovate include risk-aversion, reluctance to share control with non-family members, lack of requisite skills (Chrisman et al., 2015a), and socio-emotional concerns (Röd, 2016). It follows that family firms suffer from the willingness-ability innovation paradox that leads them to innovate less despite having a greater ability to do so. Consequently, resolving this paradox is critical to unlock their innovation potential.

In a first attempt to offer suggestions on how to resolve the innovation paradox, De Massis et al. (2015a) developed the concept of "family-driven innovation" as the set of internal strategic decisions that combine the characteristics of heterogeneous innovation decisions with drivers of family firm heterogeneity (De Massis et al., 2015a). Furthermore, Veider and Matzler (2016) investigate the willingness-ability paradox in relation to family firms' exploration and exploitation innovation strategies. The authors show that the ability of family owners interacts with their willingness to determine organizational ambidexterity - the simultaneous pursuit of exploration and exploitation. Moreover, they explain heterogeneity in family firms' innovation in terms of divergent goals, governance structures, and resources.

To sum up, existing literature mostly considers firm-level drivers to explain the controversial findings on family business innovation and resolve the willingness-ability paradox, and largely focusing on firm structure and governance. Aside from looking at the firm 
side, we argue that it is important to account for the family system and its inherent dimensions to more thoroughly understand family heterogeneity and how it affects the innovation behavior of family firms. This is consistent with recent calls to include an examination of the family and its heterogeneity to advance current knowledge of family business behavior (Jaskiewicz \& Dyer, 2017; Jaskiewicz et al., 2017). However, rather than focusing on the positive or negative effect of the family on family business innovation (Kellermanns, Eddleston, Sarathy, \& Murphy, 2012), we delve into this multifaceted phenomenon by considering the family as the core and distinctive feature of family firms and studying the relationship with family business orientation toward innovation. As such, in this study we address the question: What is the role of the family system in helping the family firm resolve the willingness-ability paradox and unlock its innovation potential?

\section{Methodology}

Beyond developing an inductive investigation, we aim to make a conceptual contribution with illustrative examples from primary and secondary evidence (Siggelkow, 2007). Our primary data rely on interviews with teams of family business consultants ${ }^{1}$ (each of them with more than 40 years' experience) on their innovation "in-depth case-stories", narratives on the innovation practices of family businesses that consulted them. We observed, collected presentations and interviewed them on the uniqueness of family business innovation. Information on family aspects is likely a very sensitive subject among family business members known for their penchant for privacy (Sharma, Hoy, Astrachan, \& Koiranen, 2007). Family business consultants who have worked for many years with the owning families are in a privileged position to gain in-depth understanding of the family aspects (Goodman, 1998). Most of the two consultants' clients that we interviewed have regularly collaborated with them for

${ }^{1}$ We interviewed and observed two Italian family business consulting firms: Cesaro \& Associati, founded in 1986 and based in Verona, and Familia, founded in 2005 and based in Milan, both operating at the national level. 
more than 20 years. From these data, we captured the relevance of family components in family business innovation. Moreover, we further conducted interviews with the family successors of three family firms to gain additional insights on the role of the succession process relative to the family-related dimensions and to exemplify how families may move between the innovation postures presented in our model.

As summarized in Table 1, we integrated primary and secondary data by selecting illustrative case studies. Among the different uses of case studies (motivation, inspiration, and illustration), we adopt illustrative cases to get closer to the discussed theoretical constructs (Siggelkow, 2007). We analyzed newspapers and trade press, websites, books, and videos to select and delve into family business cases innovating with different approaches. According to the story-telling nature of our secondary data (Hamilton, Cruz, \& Jack, 2017), we were able to trace the family side of the business, which emerges as crucial in shaping innovation. We therefore systematically collected data on the family aspects of the firms from magazine articles to further understand the underlying family dynamics. The empirical evidence is supported by specific aspects of the theoretical examination integrating family business innovation literature and family systems theory. In addition, our direct involvement in business engagement and knowledge transfer projects with family firms served as a platform to support our arguments. Consequently, the emerging theorization draws on multiple and diverse sources of information, enhancing the opportunities to integrate the theoretical and empirical insights. Our purpose is to clarify the theoretical arguments and show how the emergent conceptual issues are applied. Following Sigglekow's (2007) recommendations, we first introduce the theory and then the cases as illustration. 


\section{Family business innovation posture}

Drawing on family systems theory and family business innovation literature, this study focuses on the orientation of the family business toward innovation, namely, their innovation posture. The construct of posture as developed in strategy refers to the overall firm's competitive orientation "demonstrated by the extent to which the top managers are inclined to take business-related risks, to favor change and innovation to obtain a competitive advantage for their firm and to aggressively compete with other firms" (Covin \& Slevin, 1990: 125). Firms with a conservative strategic posture are typically risk-averse, non-innovative, and reactive; conversely, entrepreneurial strategic posture leads to risk-taking, innovativeness, and proactiveness. Therefore, the overarching construct of strategic posture is the tendency toward innovation operationalized in literature according to different dimensions, such as the level of $\mathrm{R} \& \mathrm{D}$ expenditure or the number of human resources allocated to innovation activities ( $\mathrm{Li} \&$ Atuahene-Gima, 2001).

Based on the strategic posture concept, scholars in the innovation field conceptualize innovation posture as “a firm's orientation toward innovation [that] defines the reigning culture toward introducing new products in an organization. [...] It defines the firm's overall orientation as reflected in its risk profile and competitive stance" (Calantone \& Rubera, 2012: 148). The firm's ability to engage in innovative activities is constrained by its posture; as a firm-level trait, it reflects its position in the innovation environment and the readiness to engage and benefit from innovation (Carayannis \& Provance, 2008). While an aggressive innovation posture leads to introducing a high rate of new products ahead of competitors, a firm with a defensive innovation posture would follow the market leaders by introducing fewer products with small changes. Research on innovation posture has mainly explored its impact on the firm's competitive advantage and performance, with scant attention to its antecedents.

Since innovation in family firms presents idiosyncratic characteristics due to family 
involvement in the firm's dominant coalition and in decision-making, we define the construct of family business innovation posture as the strategic orientation that the owning family particularly the family group involved in the firm's dominant coalition - imprints on the family business, shaping the firm's innovation climate, philosophy, and practices. Therefore, focusing on family business innovation posture has the potential to advance our understanding of the family's influence on innovation. Coherently with family business literature, we identify two dimensions of family business innovation posture: risk-taking propensity and tradition attachment.

Risk-taking propensity: Risk-taking propensity is defined as "the perceived probability of receiving the rewards associated with success of a proposed situation, which is required by an individual before he will subject himself to the consequences associated with failure, the alternative situation providing less reward as well as less severe consequences than the proposed situation" (Brockhaus, 1980: 513). At the individual level, CEO risk-taking propensity - the willingness of a CEO to commit significant resources to exploit opportunities or engage in behaviors with uncertain outcomes (Gilley, Walters, \& Olson, 2002) - has been identified as a driver of innovation. CEO risk-taking positively influences innovation, and its interaction with specific family firm elements (generations involved and the ratio of family members in the top management team) results in different levels of new product portfolio innovativeness (Kraiczy, Hack, \& Kellermanns, 2014). At the firm level, research shows that risk-taking propensity is lower in family firms than in their non-family counterparts (Naldi, Nordqvist, Sjöberg, \& Wiklund, 2007), and is affected by the degree of family involvement in the business (Li \& Daspit, 2016). In relation to this body of knowledge, we conceive risk-taking propensity as the family firm's proclivity to engage in behaviors with uncertain outcomes. Therefore, a family business with high risk-taking propensity tolerates uncertainty, encourages personal initiative within the family group (Isaksen \& Tidd, 2007), and boosts "out-of-the box" 
thinking. Conversely, a family firm with low risk-taking propensity prefers to "stay on the safe side" and is more cautious in gambling on some of their ideas (De Massis et al, 2015b).

Tradition attachment: Tradition includes the stock of knowledge, competencies, materials, manufacturing processes, signs, values, and beliefs pertaining to the past (Messeni Petruzzelli \& Albino, 2012). In a recent study, scholars shed light on the relevance of family business past on innovating, identifying a new product innovation strategy referred to as innovation through tradition (De Massis, Frattini, Kotlar, Petruzzelli, \& Wright, 2016). Challenging common innovation management advice to dismiss the past to make way for the future (Adner \& Snow, 2010), this innovation strategy indicates that some family firms are endowed with a unique set of capabilities that allow them to interiorize and reinterpret temporally distant knowledge to innovate by leveraging the past (De Massis et al., 2016b). According to this view, we conceive tradition attachment as the extent to which the family firm is anchored to its past and wants to transmit it to the future. Family firms with high tradition attachment share rhetorically reconstructed narratives of the family's and the founder's past behavior (Kammerlander, Dessì, Bird, Floris, \& Murru, 2015), attribute high importance to their history, celebrate their ancestors, and want to preserve their legacy over time. Conversely, family firms with low tradition attachment are more focused on the present and the future, and consider their status quo as the starting point to create something new. The past is considered as something from which the family firm has to evolve.

The combination of these two dimensions identifies a framework of different innovation postures with alternative orientations that the family can imprint on the business, shaping its innovation climate, philosophy, and practices. In relation to these two dimensions, we identify a typology of four heterogeneous combinations, each leading family firms to engage in highly innovative behavior.

\section{A typology of family business innovation postures}


Scholars in the family business field have called for typologies to enhance our understanding of different innovation approaches (Röd, 2016; Miller, Wright, Le BretonMiller, \& Scholes, 2015). As a unique form of theory building, a typology is a "conceptually derived set of ideal types [that] identifies multiple ideal types, each of which represents a unique combination of the organizational attributes that are believed to determine the relevant outcome(s)" (Doty \& Glick, 1994: 232). A typology leads to configurations by integrating contextual, structural, and strategic factors to predict variance in an outcome of interest (Doty \& Glick, 1994). This is considered valuable when including comprehensive and mutually exclusive ideal types that can be validly and reliably measured, with a clearly articulated underlying theoretical foundation (Snow \& Ketchen, 2014: 231). The configurational approach acknowledges that there is more than one way to succeed in each type of setting (Meyer, Tsui, \& Hinings, 1993), providing a theoretical underpinning for the persistence of a variety of equifinal design choices that can all lead to the desired outcome (Fiss, 2011).

Drawing on the categorization of family business innovation postures into distinct theoretical types (Cornelissen, 2017), we adopt a multidimensional approach to acknowledge the complex and interdependent nature of innovation in family business (Fiss, 2011). According to the notion of equifinality (Meyer et al., 1993), we do not assume a different degree of innovativeness among the depicted postures. Rather, we argue that family firms can adopt four different orientations to spur innovation, which we label: Seasoner, Re-enactor, Digger, Adventurer (illustrated in Figure 1). First, the Seasoner posture is characterized by low risktaking propensity, with little willingness to gamble, and low tradition attachment, shaping an innovation orientation apt to changing the meaning of current-state activity in contrast with the past without risking too much. The distinctive philosophy of this posture emerges from leveraging extant resources in a different form to develop something "tastier", without affecting the inner nature. Second, the Re-enactor family business innovation posture involves low risk- 
taking propensity combined with high tradition attachment, which leads the family firm to innovate close to the status quo. The uniqueness of the Re-enactor posture is the historical philosophy adopted to innovate by searching family business memories and inherited values, bearing little risk. Third, the Digger posture combines high tradition attachment with high risktaking propensity, boosting the intertwining of unique traditional organizational resources and capabilities, based on legacy and historical roots, with contemporary ones in order to innovate. Finally, the Adventurer's high risk-taking propensity and low tradition attachment lead family firms adopting this posture to innovate by distancing from the past and undertaking risky activities. The Adventurers' distinctive trait emerges from their daring attempt to innovate beyond the trends. The philosophy of family firms adopting this posture is to challenge the status quo by innovating. History is used by leveraging the accumulated expertise in creating something distant from current and past activities.

\section{----- Insert Figure 1 about here -----}

All the identified family business innovation postures can lead to highly innovative behavior and high innovation performance. Our aim here is to highlight the possibility of having heterogeneous orientations toward innovation and theoretically draw on the traits of each posture included in our typology. To extend our speculation, we shed light on the nuances of family business innovation posture by spanning the boundaries of our theorization beyond the business system, looking at the family system dimensions that shape family business innovation, providing cues to resolve the willingness-ability paradox.

\section{Family system and family business innovation: The interplay of family goal diversity} and family cohesion

Family science offers theories that describe family processes and outcomes. In a recent article, Jaskiewicz et al. (2017) call for further integration of family science in management 
research drawing on sociology, psychology, and education. Jaskiewicz \& Dyer (2017) outline four dimensions of family heterogeneity from family science to explore family businesses: family (member) interactions, family functions, family events, and family structures. Family systems theory explores the relevance of family member interactions for family business outcomes, conceiving the family system as interactive, complex, open, and hierarchical, wherein family members strive to maintain equilibrium (Jaskiewicz et al., 2017). Therefore, family systems theory focuses on the interactions among people rather than on the structure and characteristics (von Bertalanffy, 1968), where communication among family members is considered crucial to determining the family's status quo (Fitzpatrick \& Ritchie, 1994; Ritchie \& Fitzpatrick, 1990). The family system establishes membership criteria, rules, and rituals, and represents the ideal ground for integrating family science (in particular family systems theory) and existing management theory to gain further understanding of organizational phenomena, such as innovation.

Delving into the family business outcomes of decision-making processes requires accounting for the characteristics of family member interactions (Jasckiewicz \& Dyer, 2017). Scholars argue that the salience of different goals depends on the power of individuals or groups of individuals involved in the decision-making processes (e.g. Cameron, 1978). According to extant research, the idiosyncratic concentration of ownership and management that characterizes family firms should benefit the dominant coalition in terms of higher power to impose its will upon the firm (Chrisman, Chua, Pearson, \& Barnett, 2012). Scholars have defined the family firm as a "business held by a dominant coalition controlled by members of the same family or a small number of families" (Chua, Chrisman, \& Sharma, 1999:25). However, the family is not always a cohesive group (Aldrich \& Cliff, 2003; Rogoff \& Heck, 2003; Dyer, 2006), and low cohesion may undermine the dominant coalition. Moreover, research on goal setting challenges the assumptions in family business literature that owning 
families pursue homogeneous aspirations and goals (De Massis, Kotlar, Mazzola, Minola \& Sciascia, 2018; Kotlar \& De Massis, 2013). Therefore, two dimensions emerge as crucial in our exploration of the family system: family goal diversity and family cohesion. We investigate these two dimensions in our attempt to craft a contribution to family business innovation research.

Family goal diversity. Literature considers goal alignment as beneficial to coordination, lessening the debate between different parties on the firm's best interests (Sørensen, 2002). Besides economic goals, family business scholars emphasize non-economic goals as a key feature distinguishing family from non-family firms (Chrisman et al., 2012). Family business literature mostly investigates goal diversity between family and non-family firm members, assuming that family members focus on family-centered non-economic goals, such as maintaining family control and preserving family harmony, whereas non-family members focus on business-centered economic goals, such as increasing their economic payoff (e.g. Patel \& Cooper, 2014). Family members strive for a wide spectrum of individual goals, and research has found support for the contention that goal alignment among family members is not a realistic expectation (Villanueva \& Sapienza, 2009). Therefore, the interactions among the family, ownership, and business systems contribute to the pursuit of manifold individual goals which lead to family goal diversity, defined as the breadth of goals pursued by family members. Goal diversity is a neutral dimension; there is no direct positive or negative aspect to having high or low goal diversity. Higher levels of family goal diversity might lead to conflicts, for example, between generations (Davis \& Harveston, 1999) or among family members with different degrees of involvement in the business (Greenhaus \& Beutell, 1985), but can be beneficial when spurring individual interests. Conversely, low goal diversity means family members aspire to going in the same direction, for example, prioritizing family-centered noneconomic goals. However, such alignment can be detrimental because it constrains the 
development of diverging ideas.

Family cohesion. Research in family systems theory investigates dimensions that nurture family functioning. The intertwining between the family and the business represents a source of greater potential discord than in firms with other governance forms (Kellermanns \& Eddleston, 2004). Family cohesion - defined as "the emotional bonding that family members have towards one another" (Olson, 2000: 145) - is essential in accessing or creating resources, and shedding assets in situation of financial difficulties (Salvato \& Melin, 2008), since a cohesive family benefits from the bridging networks of its members, gaining, for example, eased access to new knowledge (Zahra, 2012). High cohesive families are characterized by reciprocity and altruism. Conversely, non-cohesive families tend to adopt individualistic paradigms and opportunistic behavior (Kellermanns \& Eddleston, 2004). Top management teams composed of parents as well as other family members are typically characterized by a high level of cohesion leading to a greater sense of belonging to the team and belief in the team members' abilities (Ensley \& Pearson, 2005).

However, cohesion can also severely hamper the family firm's ability to capitalize on the heterogeneous opinions of family members, insulating members from outside influences, leading to groupthink and conformity (Zahra, 2012), and reducing healthy debate (Sundaramurthy \& Kreiner, 2008).In fact, the "glue" that holds the family together through crises may also be excessive if the family lacks diversity in openness to outside perspectives. A family with a high level of cohesion shares and accumulates experiences across generations and different functional areas (Zahra, Neubaum, \& Larrañeta, 2007), and as the generations spread out, maintaining a cohesive family becomes more difficult (Davis \& Harveston, 1999, Pieper, 2007). Conversely, low family cohesion may be negative because it creates quarrels, but the absence of a strong glue that sticks people together might spur contamination from other networks outside the family and hence the development of novel ideas. 
Prior research has found that the family system has a stronger effect on organizational processes and outcomes when family members are cohesive and share common goals (Pieper, 2007; Zahra, 2012). Nevertheless, excessively low goal diversity (Kotlar \& De Massis, 2013) and excessively high family emotional bonds (Björnberg \& Nicholson, 2007) are shown to be detrimental to family firms. We argue that heterogeneous family firm behaviors stem from heterogeneity in family interactions, combining different levels of family cohesion and family goal diversity. Hence, rather than assuming a positive versus negative connotation of cohesion and goal diversity, we address the controversial findings in family business innovation literature by delving into the combination of high and low levels of the two family system dimensions.

\section{Ensuring the fit between family business innovation posture and the family system}

\section{dimensions}

Scholars call for further exploration of the interaction between firm and family systems (Jaskiewicz \& Dyer, 2017). We argue that innovation can thrive in family firms only if there is a fit between the family business innovation posture and the family system dimensions. Fit is defined as the "feasible sets of equally effective alternative designs, with each design internally consistent in its structural pattern and with each set matched to a configuration of contingencies" (Drazin \& Van de Ven, 1985: 520). Following this logic, we identify the configurations that ensure a fit between the family business innovation posture and family system dimensions, leading to resolving the willingness-ability paradox and thereby unlocking the family firm's innovation potential. In the following sections, we explore each family business innovation posture in depth to investigate the characteristics of each ideal type in combination with the family system characteristics, and complement this exploration with illustrative examples of family firms that have succeeded in unlocking their innovation potential by adopting the innovation posture that matches their family system characteristics. We present evidence from the four cases in Table 2, illustrating with data from each of them the fit among 
the dimensions of the family business posture and the family system.

----- Insert Table 2 about here -----

Seasoner: This family business innovation posture fits a family system characterized by low emotional bonding among family members coupled with low goal diversity. Aiming at maintaining and perpetuating the family business with scarce family cohesion, family members improve business processes and output, lacking reciprocal support to foster dramatic changes, and taking low risks. The distinctive philosophy of this posture consists in developing something "tastier", without high attachment to their legacy, and leveraging the past in a different way. As our informant reported:

"When there is a low level of closeness among family members, family businesses are too internally oriented to advance the family agenda that they miss the opportunity to follow innovative macro-trends. Nowadays, I have many examples of family firms that are not aware of the existence of Artificial Intelligence, Smart Manufacturing, Internet of Things, and Big Data. They just keep improving their output step by step thinking their business will survive forever. "(Familia Consultant) An illustrative example of the Seasoner family business innovation posture is the Luray Caverns Corporation, the third most-visited cave in the United States. The Graves siblings, two brothers and four sisters, have been aligned for years in two coalitions composed of the older versus the younger siblings, and therefore with relatively low cohesion. All the siblings pursue similar economic goals through trying to take advantage of the others. This family business innovation posture fosters numerous small changes, oftentimes in contrast with past tradition and with little risk.

Re-enactor: Fitting this family business innovation posture are families with high cohesion and low goal diversity, high attachment to their history and values, hence innovating consistently with their tradition, and low risk-taking propensity. The firm philosophy is to 
perpetuate the inherited business across generations and maintain the firm's past identity intact in the future. Family members might be hesitant to speak out and question ideas due to a type of family-imposed groupthink that characterizes these families (Janis, 1982; Pieper, 2010). As our informant reported:

"A father-founder hands over to his child not only the company keys but also all the traditional values to count on. [...] The family business embodies all the values, experiences, and identity of the family and does not want to question its past by innovating." (Cesaro \& Associati Consultant)

An exemplary case of re-enactors is the Smarties Candy Company. Run by the founder's four granddaughters with a high degree of cohesion, it has produced candies since 1949 according to the original recipe. The granddaughters share the common goal of adopting new technologies to increase their firm's efficiency, but their traditional product is perpetuated over time, and the family values and beliefs from the past are handed down from generation to generation.

Digger: Individual members of the family strive for heterogeneous goals, and the high degree of cohesion among family members channels such goal diversity toward an innovation path that fits best with a family business innovation posture with high risk propensity but attached to tradition. Since family members do not want to damage family harmony, strong cohesion may constrain individual autonomy to develop innovative projects due to less open search and frozen individual cognitive structures (König et al., 2013). As an informant reported:

"Some family businesses hold a unique and rich coffer of experiences and competencies they can rely on to innovate. When family members open the coffer, they recognize the business' inner value and exalt it through innovative outcomes, the result is extraordinary and inimitable." (Cesaro \& Associati Consultant)

Beretta is an illustrative example of the Digger family business innovation posture. The family members in Beretta - Italian gun producer since 1526 - have diverse goals, yet the family is 
highly cohesive. Beretta's orientation toward innovation is developed through acquisitions and new product development in sectors relatively close to the core business. By maintaining a strong link with the past, they have combined traditional and actual resources and capabilities to innovate for fifteen generations.

Adventurer: When family members pursue diverse individual goals and have a low level of cohesion, they fit with a family business innovation posture that allows family members to seek their independence and look for innovation opportunities in the same or different markets or sectors of the core business to distance themselves from the family nest. This family configuration fits with the Adventurer posture, wherein high risk-taking propensity and low tradition attachment ensure the freedom to develop innovation. Our informants reported:

"The 'affective storm' generated by family conflicts leads to competition and alliances among family members, envy, and jealousy." (Cesaro \& Associati Consultant)

"Sometimes it is the family that creates 'kingdoms' within the business. Two cousins or two other family members involved in the same business split into different geographic regions, one in Brazil and the other in Poland; each realm manages his/her kingdom independently without looking at what the others do or even competing with other divisions." (Familia Consultant)

An illustrative example of family firm adopting this posture is Esselunga, an Italian retail chain owned by the Caprotti family. The firm was entirely owned by Bernardo Caprotti until his death in 2016 when he left the shares to his descendants (16.7\% to each of his children from his first marriage and $66.7 \%$ to his second wife and their daughter). Family cohesion has always been relatively low with members facing manifold relational struggles and their different goals manifested in quarrels and legal disputes. This family system configuration fits with the Adventurer posture, a family orientation characterized by dissonance with respect to past 
tradition and high risk-taking propensity, which lead the family firm to develop new services and products, for example, by adopting design thinking tools.

In sum, our study sheds light on family business innovation postures by developing a typology according to high and low levels of risk-taking propensity and tradition attachment. Extending our theorization, we argue that to unlock their innovation potential, family firms need to adopt an orientation toward innovation that is coherent with their family system dimensions of cohesion and goal diversity. This fit is important to resolve the willingnessability paradox in family firm innovation.

\section{Succession as an opportunity to achieve a new fit}

The family and the business are dynamic systems that change over time (Gersick, Davis, Hampton, \& Lansberg, 1997). Succession is one of the most dramatic changes in the life of any family firm (De Massis, Chua, \& Chrisman, 2008) and is likely to alter the two family system dimensions of family goal diversity and family cohesion. Furthermore, succession offers an ideal opportunity to calibrate the levels of risk-taking propensity and tradition attachment characterizing the family business innovation posture. Such changes allow resolving the willingness-ability paradox by either continuing to be innovative, switching from one ideal type to another, or moving to a new configuration that unlocks the firm's innovation potential. To explore this argument, we identify three illustrative examples of family firms that have found a new configuration through succession (Stew Leonard's, Amramp, and Liang Ping), ensuring a new fit between the family business innovation posture and the family system dimensions. We conducted interviews with the successors of three family businesses who joined their firm after some work experience in other organizations, discussing their family and business and how their takeover would change their family business innovation posture.

The first informant belongs to the third generation of a very cohesive family in the retail industry. The second generation had relatively low goal diversity combined with relatively low 
risk-taking propensity and high tradition attachment, coherent with the Re-enactor innovation posture, leading the firm to grow and prosper by increasing the number of stores while maintaining their legacy intact. With succession, the family firm maintained the fit between the family business innovation posture and family system dimensions by changing their innovation posture. When the third generation joined the business, both the family goal diversity and risktaking propensity increased, and to unlock the innovation potential, the family business adopted an innovation posture coherent with the Digger type. The incoming third generation uses existing business resources to develop creative products, coherent with their tradition of high quality and fresh food, but also taking risks by following current trends and using actual resources:

"We have very strong family connections, but we know that no-one is going to think the same way. The second generation's goal was to physically build up the stores and they grew from twelve to three thousand. We, as the third generation, have to continue the business by innovating in different ways, looking at industry changes. We capitalize on the resources of the second generation and keep them on the board to complement our competencies, since you have to keep up with the trends. The good thing about our business is that if we see something new we just try it. A lot of things don't work, and that's fine, but if we find one that works, that's brilliant! For example, I saw the 'sushi donuts' somewhere online. We have a sushi department in each of our stores and we tried this new thing with one; it was successful so now we are implementing it in other stores." (Andrew Hollis, Stew Leonard's)

The former generation of the second illustrative case was characterized by low cohesion and low goal diversity in the family system, combined with low tradition attachment and risk-taking propensity in the family business. This configuration allowed the firm to grow and prosper in the past according to the Seasoner innovation posture. However, with the incumbent getting 
older, the level of attachment to tradition increased. This configuration led to a mismatch between the family business innovation posture and the family system dimensions. As such, the family business was trapped in the willingness-ability innovation paradox. The product the firm was offering had been the same for many years and the relatively low level of innovation was hampering customer satisfaction. With the involvement of the second generation, business goal diversity and risk-taking propensity increased, while attachment to tradition decreased. This change led to a configuration coherent with the Adventurer family business innovation posture and family system fit. By offering breakthrough changes in the product, the firm innovation potential was unlocked:

"I know we score low on cohesion and bonding and I think this helped us to innovate. Any attempt to change the product or create a separate product line would be shut down by my father. He would shut down projects that did not match his vision as the entrepreneur and founder. Have you ever tried to explain the value proposition of cloud-based CRM to a 70-year-old engineer who keeps track of how many cuts he can get out of a metal saw blade before it is worn out? However, about two years ago, he semi-retired and I gave two key engineers leeway to produce a new purpose-built product that we kept hidden from my father until we were ready for release." (Justin Gordon, Amramp)

The third informant is entering a family business highly attached to tradition with low risktaking propensity, while the family has high goal diversity and cohesion. This mismatch is hampering innovation in the firm. As a second-generation family member approaching succession, he aims to continue the business consistently with the past while investing in innovation to adapt the traditional product to new customer trends. To do so, he intends to increase the risk-taking propensity, coherently with the Re-enactor family business innovation 
posture. This orientation has proven promising in allowing the family business to resolve the willingness-ability paradox and innovate.

"Our family is cohesive, we operate in more than ten cities and the leader of each city is either my uncle or aunt on my father's and on my mother's side. Basically, they share the same goal of making the family business better. We make tea, a traditional product. The first generation does not want to spend too much time and money on innovation, because it does not want to take risks and cares about every cent we make. This is the second generation's job. I am thinking about how to take over the business and do some significant new things to gain young people's attention. I would like to stick with tradition, adding more flavors to tea and make the process easier. Chinese tea takes time to brew and the quick solutions that you find do not taste the same." (Sheng Sheng Glen, Liang Ping)

The three examples above illustrate that succession offers the opportunity to re-calibrate the family business innovation posture and family system dimensions. This allows family firms to resolve the paradox by either switching from one innovation posture to another or by fostering a fit between the family business innovation posture and the family system dimensions.

\section{Discussion}

Family business research calls for further integrating family aspects in investigating firmlevel phenomena (Jaskiewicz \& Dyer, 2017). Innovation is one of the most controversial processes of family firms, which are generally portrayed as conservative yet producing higher innovation outputs (Duran et al., 2016). However, family business literature has mostly focused on the business dynamics of innovation, overlooking the family system (De Massis et al., 2015a, De Massis et al., 2016a). Scholars argue that family businesses suffer from a "willingnessability innovation paradox": although they are typically more able to innovate than their non- 
family counterparts, most do not do so, and whether they do or not depends on their willingness (Chrisman et al., 2015a).

In investigating family firm innovation, we develop the construct of family business innovation posture as the strategic orientation that the owning family - particularly the family group involved in the firm's dominant coalition - imprints on the family business, shaping the firm's innovation climate, philosophy, and practices. In analyzing family business innovation posture, we identify two dimensions: risk-taking propensity and tradition attachment. We develop a typology of four family business innovation postures according to low vs. high levels of risk propensity and tradition attachment: Seasoner, Re-enactor, Digger, Adventurer. The four equifinal postures imprint an innovation orientation toward the business characterized by different traits. However, identifying the posture is not sufficient to resolve the willingnessability paradox. By underscoring the importance of the family system dimensions, we argue that it is necessary to ensure a fit between the family business innovation posture and the family system dimensions (family goal diversity and family cohesion) to resolve the paradox and unlock the family business innovation potential. Therefore, we theoretically explore the combinations of the four identified dimensions that ensure a fit, and provide illustrative examples of innovating family businesses coherent with our configurations. Finally, we discuss succession as a key opportunity to calibrate the family business innovation posture and family system dimensions to resolve the paradox.

This study offers three major contributions to literature. First, by introducing the construct and developing a typology of family business innovation postures, we contribute to innovation literature by highlighting four equifinal orientations toward innovation. Second, by observing the family dimensions of goal diversity and cohesion, we address the call to further integrate family aspects in family business and innovation studies (Jasckiewicz \& Dyer, 2017). Third, our exploration of fit between the family-related dimensions and innovation posture helps 
clarify some important mechanisms to resolve the willingness-ability paradox of family business innovation, and better interpret some of the findings from existing research.

Our first contribution consists in introducing a typology of family business innovation posture. We observed that the climate, philosophy, and practices of the family business are strongly influenced by the two dimensions of risk-taking propensity and tradition attachment. Addressing the call of Röd (2016) for typologies in family business innovation, we develop a $2 \times 2$ matrix according to high vs. low levels of the two dimensions, unveiling heterogeneous configurations in the orientation toward innovation, labelled Seasoner, Re-enactor, Digger and Adventurer, equally able to spur innovative activities in family business. Therefore, our study demonstrates not only that family firms can indeed be innovative, but also explains the diverse ways in which family firms can innovate.

The second contribution of this study is in integrating family business innovation literature and family systems theory. We do so by building our theoretical speculation on two crucial dimensions: family goal diversity and family cohesion. We argue that the two family system dimensions need to be calibrated in accordance with the family business innovation posture. In doing so, we address the call to further integrate family aspects in family business (Jasckiewicz \& Dyer, 2017) and innovation research (De Massis et al., 2015a). By delving into family systems theory, we consider nuances in the relationships among family members in relation to family business innovation, showing that family unity and family goal alignment are beneficial for family business innovation (Chirico \& Salvato, 2016), but that low family cohesion and high family goal diversity can also foster innovation. What is important is that the family business adopts an innovation posture that fits with the family system dimensions so as to leverage its strengths and circumvent its weaknesses.

Third, this study provides further clarification to the debate on the willingness-ability paradox of family business innovation (Chrisman et al., 2015a). By ensuring a fit between the 
illustrated dimensions, family businesses can resolve the paradox and unlock their innovation potential. Our theoretical examination and illustrations through exemplary cases suggest that family businesses that are able but unwilling to innovate should revise their innovation posture or family system dimensions. Succession offers the opportunity to alter these dimensions and re-calibrate the family business innovation posture, thereby unlocking the firm's innovation potential.

Ultimately, our study is about achieving "fit" between the family and the business. As such, it contributes useful new insights to the long-debated conversation on balancing/reconciling the family and business systems (Tagiuri \& Davis, 1996; Ward, 1997) - on both practical and theoretical grounds. In terms of implications for practice, our typology offers to family business owners, managers, and consultants the opportunity to assess the fit between the family business innovation posture and the key dimensions of the family system. As such, our proposed typology serves as a tool to assess the consistency conditions that are particularly important to promote innovation in family firms. Practitioners should recognize that when there is a misfit between these aspects, unlocking the innovation potential of family firms is difficult and sometimes even impossible. However, they should not interpret this typology as static, since they can change their firm's posture by altering the illustrated dimensions, both in the family system and in the family business. Therefore, practitioners, prior to making decisions on their innovation activities, should carefully diagnose the characteristics of their firm's innovation posture in terms of risk-taking and tradition attachment, and those of their family in terms of goal diversity and cohesion, eventually acting on these to achieve the fit. Crucial events such as succession are good opportunities to alter the dimensions and achieve a new fit.

As with all studies, ours has limitations, which also provide opportunities for future research. First, we investigated the influence of family aspects on the family business innovation posture by looking at the cohesion and goal diversity dimensions at the family level. 
However, within families, there are leaders with greater power than others who may be better able to influence the family business orientation, as well as within-family coalitions with heterogeneous levels of goal diversity and cohesion that therefore strive for a different family business innovation posture. As an example, literature distinguishes between parental and familial top management teams (Ensley \& Pearson, 2005), identifying different dynamics. Future empirical inquiry could consider these family dynamics to unveil the interaction between innovation and specific aspects of family top management teams, such as intra-generational solidarity (Jasckiewicz \& Dyer, 2017). Moreover, we encourage future scholars to reflect more deeply on the functions and structures of families and their impact on family business innovation by exploring other sources of family heterogeneity, such as family events, family functions, and family structure (Jasckiewicz \& Dyer, 2017). For instance, family functionality (Smilkstein, 1978), referring to family functional integrity and the stability of relationships among family members, has been shown to indirectly shape family firms' capacity to innovate (Filser, De Massis, Gast, Kraus, \& Niemand, 2017). Advancing the call for further integration of family science and existing management theory, it would also be interesting to adopt extant models of family systems theory, such as the circumplex model (Olson, Sprenkle, \& Russell, 1979), to investigate family member interactions in relation to innovation.

Second, this study assumes high and low level extremes of the key dimensions characterizing family business innovation posture and family system. However, including nuances in this dichotomy may contribute to developing further understanding of the configurations that resolve the willingness-ability paradox. We envisage future quantitative and qualitative studies that develop and employ more nuanced scales to capture the key constructs in our investigation and take into account the process that leads a family business to change the levels of the dimensions in the family system or in family business innovation posture toward a new fit. 
Third, in developing our typology, we assumed that family businesses adopt an innovation posture. However, the types are dynamic and subject to change. Future research could take a dynamic approach and examine the temporal evolution of family business innovation postures. For example, our preliminary interviews with three family business successors revealed that the imminence of an intra-family succession triggers the unfreezing of previously established and new organizational goals, activating social interactions that reshape both goal diversity and cohesion. Therefore, succession seems to offer an ideal opportunity for family firms to modify their innovation posture in relation to the family system dimensions and strive for a better fit. There might be other processes, either in the family (e.g. marriage, divorce, births) or in the firm (acquisitions, internationalization), that shape the configuration and enable a fit among the different dimensions. Future research could explore the existence of transition patterns from one type of family business innovation posture to another. Our examples of the succession process show that the dimensions do not change simultaneously, but family businesses of one ideal type encounter various phases of absent fit before reaching the new ideal type. Therefore, situations of poor fit might be needed to transit from one ideal type to another. Unfortunately, literature remains rather silent on this issue (Hauck \& Prügl, 2015) and we encourage future scholars to build on our observation to investigate how situational factors, such as the imminence of an intra-family succession or the involvement of outside professionals (Chrisman, Fang, Kotlar \& De Massis, 2015), may affect the mechanisms leading to consistency between innovation posture and the family system dimensions.

Fourth, our study examines illustrative examples of family firms that innovated in different environmental contexts. For instance, we observed that in our exemplary cases, the context varied in terms of environmental munificence and competition. Such environmental factors may be contingencies of the fit mechanisms under investigation. Indeed, the fit between the family-related dimensions and family business innovation posture is a necessary condition to 
resolve the willingness-ability innovation paradox. Thus, we encourage future scholars to consider varying sources of heterogeneity in environmental contexts, such as different levels of environmental munificence and competition, and investigate how such environmental contingencies may affect the mechanisms behind the adoption of a specific family business posture to fit a given configuration of family cohesion and family goal diversity. Moreover, although we examined family firm exemplars renowned for their innovation, we welcome future studies that explicitly measure innovation performance across different indicators, for example, number of new patents obtained and expansion into new markets (Cucculelli, Le Breton-Miller, \& Miller, 2016) or patent citations (Block, Miller, Jaskiewicz, \& Spiegel, 2013), as this would add further nuances to our understanding of what distinguishes high from low innovation family firms and the relationships between such differences and the fit mechanisms. Ideally, such studies should be longitudinal to ensure capturing the cause-effect and temporal relationships between the fit mechanisms and the innovation performance outcome.

Last, we use exemplary cases as illustrations to illuminate the basic tenets of our typology of family firm postures. Of course, more empirical research is needed to further elaborate on this typology and test our contentions. We therefore encourage future studies to employ both qualitative methods, such as inductive case studies, and quantitative methods. We invite scholars to also investigate situations of poor fit between the family firm innovation posture and a given configuration in terms of family goal diversity and family cohesion, since these detrimental circumstances can be particularly insightful. As an example, the presence of a "Fredo" - an incompetent and opportunistic family member accustomed to ethically dubious actions (Kidwell, Kellermanns, Eddleston, 2012) - would call for either the Adventurer or Seasoner posture due to low family cohesion and high goal diversity. Those family businesses that in such circumstances adopt a different innovation posture may miss the opportunity to resolve the willingness-ability paradox to fully unlock their innovation potential. 


\section{Conclusion}

Family businesses are often considered conservative and reluctant to innovate yet figure among the most innovative firms. This study investigates the interaction between the family and the business systems, unveiling the relationship between the family system dimensions (family cohesion and goal diversity) and family business innovation posture (introduced as a new construct in relation to risk-taking propensity and tradition attachment). Furthermore, we develop a typology of family business innovation postures identifying four types: Seasoner, Reenactor, Digger, and Adventurer. For each of the identified postures, we provide data from consultants' experiences and illustrative cases. Our study suggests that attaining a fit between family business innovation posture and the family system dimensions is a necessary condition to resolve the willingness-ability innovation paradox of family firms and unlock their innovation potential. Moreover, our study underscores the opportunity offered by succession to achieve such fit. In sum, the typology presented in this article extends current research on family business innovation while also providing important insights for family business owners, managers, and consultants. 


\section{References}

Adner, R., \& Snow, D. (2010). Old technology responses to new technology threats: Demand heterogeneity and technology retreats. Industrial and Corporate Change, 19(5), 16551675.

Aldrich, H. E., \& Cliff, J. E. (2003). The pervasive effects of family on entrepreneurship: Toward a family embeddedness perspective. Journal of Business Venturing, 18, 573-596.

Björnberg, Å., \& Nicholson, N. (2007). The family climate scales-Development of a new measure for use in family business research. Family Business Review, 20(3), 229-246.

Block, J., Miller, D., Jaskiewicz, P., \& Spiegel, F. (2013). Economic and technological importance of innovations in large family and founder firms: An analysis of patent data. Family Business Review, 26(2), 180-199. SLE:

Blundell, R., Griffith, R., \& Van Reenen, J. (1999). Market share, market value and innovation in a panel of British manufacturing firms. The Review of Economic Studies, 66(3), 529554 .

Brockhaus, R. H. (1980). Risk taking propensity of entrepreneurs. Academy of Management Journal, 23(3), 509-520.

Calantone, R.J., Chan, K. \& Cui, A.S. (2006). Decomposing product innovativeness and its effects on new product success. Journal of Product Innovation Management, 23(5), 408421.

Calantone, R., \& Rubera, G. (2012). When should RD\&E and marketing collaborate? The moderating role of exploration-exploitation and environmental uncertainty. Journal of Product Innovation Management, 29(1), 144-157.

Cameron, K. (1978). Measuring organizational effectiveness in institutions of higher education. Administrative Science Quarterly, 23(4), 604-632.

Carayannis, E. G., \& Provance, M. (2008). Measuring firm innovativeness: towards a composite innovation index built on firm innovative posture, propensity and performance attributes. International Journal of Innovation and Regional Development, 1(1), 90-107.

Chirico, F., \& Salvato, C. (2016). Knowledge internalization and product development in family firms: When relational and affective factors matter. Entrepreneurship Theory and Practice, 40(1), 201-229.

Chrisman, J. J., Chua, J. H., De Massis, A., Frattini, F., \& Wright, M. (2015a). The ability and willingness paradox in family firm innovation. Journal of Product Innovation Management, 32(3), 310-318.

Chrisman, J. J., Chua, J. H., Pearson, A. W., \& Barnett, T. (2012). Family involvement, family influence, and family-centered non-economic goals in small firms. Entrepreneurship Theory and Practice, 36(2), 267-293.

Chrisman, J. J., Fang, H., Kotlar, J., \& De Massis, A. (2015b). A note on family influence and the adoption of discontinuous technologies in family firms. Journal of Product Innovation Management, 32(3), 384-388.

Chrisman, J. J., \& Patel, P. C. (2012). Variations in R\&D investments of family and nonfamily firms: Behavioral agency and myopic loss aversion perspectives. Academy of Management Journal, 55(4), 976-997. 
Chua, J. H., Chrisman, J. J., \& Sharma, P. (1999). Defining the family business by behavior. Entrepreneurship: Theory and Practice, 23(4), 19-19.

Cornelissen, J. (2017). Editor's comments: Developing propositions, a process model, or a typology? Addressing the challenges of writing theory without a boilerplate. Academy of Management Review, 42(1), 1-9.

Covin, J. G., \& Slevin, D. P. (1990). New venture strategic posture, structure, and performance: An industry life cycle analysis. Journal of Business Venturing, 5(2), 123-135.

Craig, J., \& Dibrell, C. (2006). The natural environment, innovation, and firm performance: A comparative study. Family Business Review, 19(4), 275-288.

Cucculelli, M., Le Breton-Miller, I., \& Miller, D. (2016). Product innovation, firm renewal and family governance. Journal of Family Business Strategy, 7(2), 90-104.

Davis, P. S., \& Harveston, P. D. (1999). In the founder's shadow: Conflict in the family firm. Family Business Review, 12(4), 311-323.

De Massis, A., Audretsch, D., Uhlaner, L., \& Kammerlander, N. (2018). Innovation with limited resources: Management lessons from the German Mittelstand. Journal of Product Innovation Management, 35(1), 125-146. DOI: 10.1111/jpim.12373.

De Massis, A., Chua, J. H., \& Chrisman, J. J. (2008). Factors preventing intra-family succession. Family Business Review, 21(2), 183-199.

De Massis, A., Di Minin, A., \& Frattini, F. (2015a). Family-driven innovation: Resolving the paradox in family firms. California Management Review, 58(1), 5-19.

De Massis, A., Frattini, F., Kotlar, J., Petruzzelli, A. M., \& Wright, M. (2016b). Innovation through tradition: Lessons from innovative family businesses and directions for future research. Academy of Management Perspectives, 30(1), 93-116.

De Massis, A., Frattini, F., \& Lichtenthaler, U. (2013). Research on technological innovation in family firms: Present debates and future directions. Family Business Review, 26(1), 1031.

De Massis, A., Frattini, F., Pizzurno, E., \& Cassia, L. (2015b). Product innovation in family versus non-family firms: An exploratory analysis. Journal of Small Business Management, 53(1), 1-36.

De Massis, A., Kotlar, J., Chua, J. H., \& Chrisman, J. J. (2014). Ability and willingness as sufficiency conditions for family-oriented particularistic behavior: implications for theory and empirical studies. Journal of Small Business Management, 52(2), 344-364.

De Massis, A., Kotlar, J., Frattini, F., Chrisman, J. J., \& Nordqvist, M. (2016a). Family governance at work: Organizing for new product development in family SMEs. Family Business Review, 29(2), 189-213.

De Massis, A., Kotlar, J., Mazzola, P., Minola, T., \& Sciascia, S. (2018). Conflicting selves: Family owners' multiple goals and self-control agency problems in private firms. Entrepreneurship Theory \& Practice, 42(4).

Dyer, W. G. (2006). Examining the family effect on firm performance. Family Business Review, 19(4), $253-273$.

Doty, D. H., \& Glick, W. H. (1994). Typologies as a unique form of theory building: Toward improved understanding and modeling. Academy of Management Review, 19(2), 230-251.

Drazin, R., \& Van de Ven, A. H. (1985). Alternative forms of fit in contingency theory. Administrative Science Quarterly, 514-539. 
Duran, P., Kammerlander, N., Van Essen, M., \& Zellweger, T. (2016). Doing more with less: Innovation input and output in family firms. Academy of Management Journal, 59(4), 1224-1264.

Economist. Dynasties and durability. (2009). Available at http://www.economist.com/node/14517406. Accessed 03.13.2017.

Ensley, M. D., \& Pearson, A. W. (2005). An exploratory comparison of the behavioral dynamics of top management teams in family and nonfamily new ventures: Cohesion, conflict, potency, and consensus. Entrepreneurship Theory and Practice, 29(3), 267-284.

Filser, M., De Massis, A., Gast, J., Kraus, S., \& Niemand, T. (2017). Tracing the roots of innovativeness in family SMEs: The effect of family functionality and socioemotional wealth. Journal of Product Innovation Management, Forthcoming.

Fiss, P. C. (2011). Building better causal theories: A fuzzy set approach to typologies in organization research. Academy of Management Journal, 54(2), 393-420.

Fitzpatrick, M. A., \& Ritchie, L. D. (1994). Communication schemata within the family. Human Communication Research, 20(3), 275-301.

Forbes. The world's most innovative companies. (2014). Available at www.forbes.com/innovativecompanies/list/\#page:1_sort:0_direction:asc_search:_filter;All\%20industries. Accessed 03.29.2017.

Freeman, C. (1976). Economics of industrial innovation. London, England: Pinter.

Garud, R., Tuertscher, P., \& Van de Ven, A. H. (2013). Perspectives on innovation processes. Academy of Management Annals, 7(1), 775-819.

Gersick, K. E., Davis, J. A., Hampton, M. M., \& Lansberg, I. (1997). Generation to generation. Cambridge, MA: Harvard Business School Press.

Gilley, K. M., Walters, B. A., \& Olson, B. J. (2002). Top management team risk taking propensities and firm performance: Direct and moderating effects. Journal of Business Strategies, 19(2), 95.

Gomez-Mejia, L. R., Campbell, J. T., Martin, G., Hoskisson, R. E., Makri, M., \& Sirmon, D. G. (2014). Socioemotional wealth as a mixed gamble: Revisiting family firm R\&D investments with the behavioral agency model. Entrepreneurship Theory and Practice, 38(6), 1351-1374.

Goodman, J. M. (1998). Defining the new professional: The family business counselor. Family Business Review, 11(4), 349-354.

Greenhaus, J. H., \& Beutell, N. J. (1985). Sources of conflict between work and family roles. Academy of Management Review, 10(1), 76-88.

Hamilton, E., Cruz, A. D., \& Jack, S. (2017). Re-framing the status of narrative in family business research: Towards an understanding of families in business. Journal of Family Business Strategy, 8(1), 3-12.

Hauck, J., \& Prügl, R. (2015). Innovation activities during intra-family leadership succession in family firms: An empirical study from a socioemotional wealth perspective. Journal of Family Business Strategy, 6(2), 104-118.

Isaksen, S. G., \& Tidd, J. (2007). Meeting the innovation challenge: Leadership for transformation and growth. Wiley. 
Janis, I. L. (1982). Groupthink: Psychological studies of policy decisions and fiascoes (Second Edition). New York, NY: Houghton Mifflin.

Jaskiewicz, P., Combs, J., Shanine, K., \& Kacmar, M. (2017). Introducing the family: A review of family science with implications for management research. Academy of Management Annals.

Jaskiewicz, P., \& Dyer, (2017). Addressing the elephant in the room: Dis-entangling family heterogeneity to advance family business research. Family Business Review, 30(2), 111118 .

Kammerlander, N., Dessì, C., Bird, M., Floris, M., \& Murru, A. (2015). The impact of shared stories on family firm innovation: A multicase study. Family Business Review, 28(4), 332354.

Kammerlander, N., \& Van Essen, M. (2017). Research: Family firms are more innovative than other companies. Harvard Business Review. Available at: https://hbr.org/2017/01/research-family-firms-are-more-innovative-than-othercompanies. Accessed 03.29.2017.

Kellermanns, F. W., \& Eddleston, K. A. (2004). Feuding families: When conflict does a family firm good. Entrepreneurship Theory and Practice, 28(3), 209-228.

Kellermanns, F. W., Eddleston, K. A., Sarathy, R., \& Murphy, F. (2012). Innovativeness in family firms: A family influence perspective. Small Business Economics, 38(1), 85-101.

Kidwell, R. E., Kellermanns, F. W., \& Eddleston, K. A. (2012). Harmony, justice, confusion, and conflict in family firms: Implications for ethical climate and the "Fredo effect”. Journal of Business Ethics, 106(4), 503-517.

König, A., Kammerlander, N., \& Enders, A. (2013). The family innovator's dilemma: How family influence affects the adoption of discontinuous technologies by incumbent firms. Academy of Management Review, 38(3), 418-441.

Kotlar, J., \& De Massis, A. (2013). Goal setting in family firms: Goal diversity, social interactions, and collective commitment to family-centered goals. Entrepreneurship Theory and Practice, 37(6), 1263-1288.

Kotlar, J., De Massis, A., Frattini, F., Bianchi, M., \& Fang, H. (2013). Technology acquisition in family and nonfamily firms: A longitudinal analysis of Spanish manufacturing firms. Journal of Product Innovation Management, 30(6), 1073-1088.

Kraiczy, N. D., Hack, A., \& Kellermanns, F. W. (2014). New product portfolio performance in family firms. Journal of Business Research, 67(6), 1065-1073.

Li, H., \& Atuahene-Gima, K. (2001). Product innovation strategy and the performance of new technology ventures in China. Academy of Management Journal, 44(6), 1123-1134.

Li, Z., \& Daspit, J. J. (2016). Understanding family firm innovation heterogeneity: A typology of family governance and socioemotional wealth intentions. Journal of Family Business Management, 6(2), 103-121.

Messeni Petruzzelli, A., \& Albino, V. (2012). When tradition turns into innovation. How firms can create and appropriate value through tradition. Oxford, UK: Woodhead Publishing Limited.

Meyer, A. D., Tsui, A. S., \& Hinings, C. R. (1993). Configurational approaches to organizational analysis. Academy of Management journal, 36(6), 1175-1195. 
Miller, D., Wright, M., Le Breton-Miller, I., \& Scholes, L. (2015). Resources and innovation in family businesses. California Management Review, 58(1), 20-40.

Naldi, L., Nordqvist, M., Sjöberg, K., \& Wiklund, J. (2007). Entrepreneurial orientation, risk taking, and performance in family firms. Family Business Review, 20(1), 33-47.

Nieto, M. J., Santamaria, L., \& Fernandez, Z. (2015). Understanding the innovation behavior of family firms. Journal of Small Business Management, 53(2), 382-399.

Olson, D. H. (2000). Circumplex model of marital and family systems. Journal of Family Therapy, 22(2), 144-167.

Olson, D. H., Sprenkle, D. H., \& Russell, C. S. (1979). Circumplex model of marital and family systems: I. Cohesion and adaptability dimensions, family types, and clinical applications. Family Process, 18(1), 3-28.

Patel, P. C., \& Chrisman, J. J. (2014). Risk abatement as a strategy for R\&D investments in family firms. Strategic Management Journal, 35(4), 617-627.

Patel, P. C., \& Cooper, D. (2014). Structural power equality between family and non-family TMT members and the performance of family firms. Academy of Management Journal, 57(6), 1624-1649.

Pieper, T. M. (2007). Mechanisms to assure long-term family business survival: A study of the dynamics of cohesion in multigenerational family business families. Frankfurt, Germany: Peter Lang Publishing.

Pieper, T. M. (2010). Non solus: Toward a psychology of family business. Journal of Family Business Strategy, 1(1), 26-39.

Ritchie, L. D., \& Fitzpatrick, M. A. (1990). Family communication patterns: Measuring intrapersonal perceptions of interpersonal relationships. Communication Research, 17(4), 523-544.

Röd, I. (2016). Disentangling the family firm's innovation process: A systematic review. Journal of Family Business Strategy, 7(3), 185-201.

Rogoff, E. G., \& Heck, R. K. Z. (2003). Evolving research in entrepreneurship and family business: Recognizing family as the oxygen that feeds the fire of entrepreneurship. Journal of Business Venturing, 18, 559-566.

Salvato, C., \& Melin, L. (2008). Creating value across generations in family-controlled businesses: The role of family social capital. Family Business Review, 21(3), 259-276.

Sharma, P., Hoy, F., Astrachan, J. H., \& Koiranen, M. (2007). The practice-driven evolution of family business education. Journal of Business Research, 60(10), 1012-1021.

Siggelkow, N. (2007). Persuasion with case studies. Academy of Management Journal, 50, 20 24.

Smilkstein, G. (1978). The family APGAR: A proposal for a family function test and its use by physicians. The Journal of Family Practice, 6(6), 1231-1239.

Snow, C. C., \& Ketchen, D. J. (2014). Typology-driven theorizing: A response to Delbridge and Fiss. Academy of Management Review, 39(2), 231-233.

Sørensen, J. B. (2002). The strength of corporate culture and the reliability of firm performance. Administrative Science Quarterly, 47(1), 70-91.

Sundaramurthy, C., \& Kreiner, G. E. (2008). Governing by managing identity boundaries: The case of family businesses. Entrepreneurship Theory and Practice, 32(3), 415-436. 
Tagiuri, R., \& Davis, J. (1996). Bivalent attributes of the family firm. Family Business Review, 9(2), 199-208.

Urbinati, A., Franzò S., De Massis, A., Frattini, F. (2017). Innovation in family firms: A review of prior studies and a framework for future research. In Brem A., Viardot E. (Eds.). Revolution of innovation management - internationalization and business models, Palgrave MacMillan, Basingstoke, Hampshire, UK.

Veider, V., \& Matzler, K. (2016). The ability and willingness of family-controlled firms to arrive at organizational ambidexterity. Journal of Family Business Strategy, 7(2), 105-116.

Villanueva, J., \& Sapienza, H. J. (2009). Goal tolerance, outside investors, and family firm governance. Entrepreneurship Theory and Practice, 33(6), 1193-1199.

Von Bertalanffy, L. (1968). General system theory: Foundations, development, applications. New York, NY: George Braziller Inc.

Ward, J. L. (1997). Growing the family business: Special challenges and best practices. Family Business Review, 10(4), 323-337.

Zahra, S. A. (2012). Organizational learning and entrepreneurship in family firms: Exploring the moderating effect of ownership and cohesion. Small Business Economics, 38(1), 5165 .

Zahra, S. A., Neubaum, D. O., \& Larrañeta, B. (2007). Knowledge sharing and technological capabilities: The moderating role of family involvement. Journal of Business Research, 60(10), 1070-1079. 


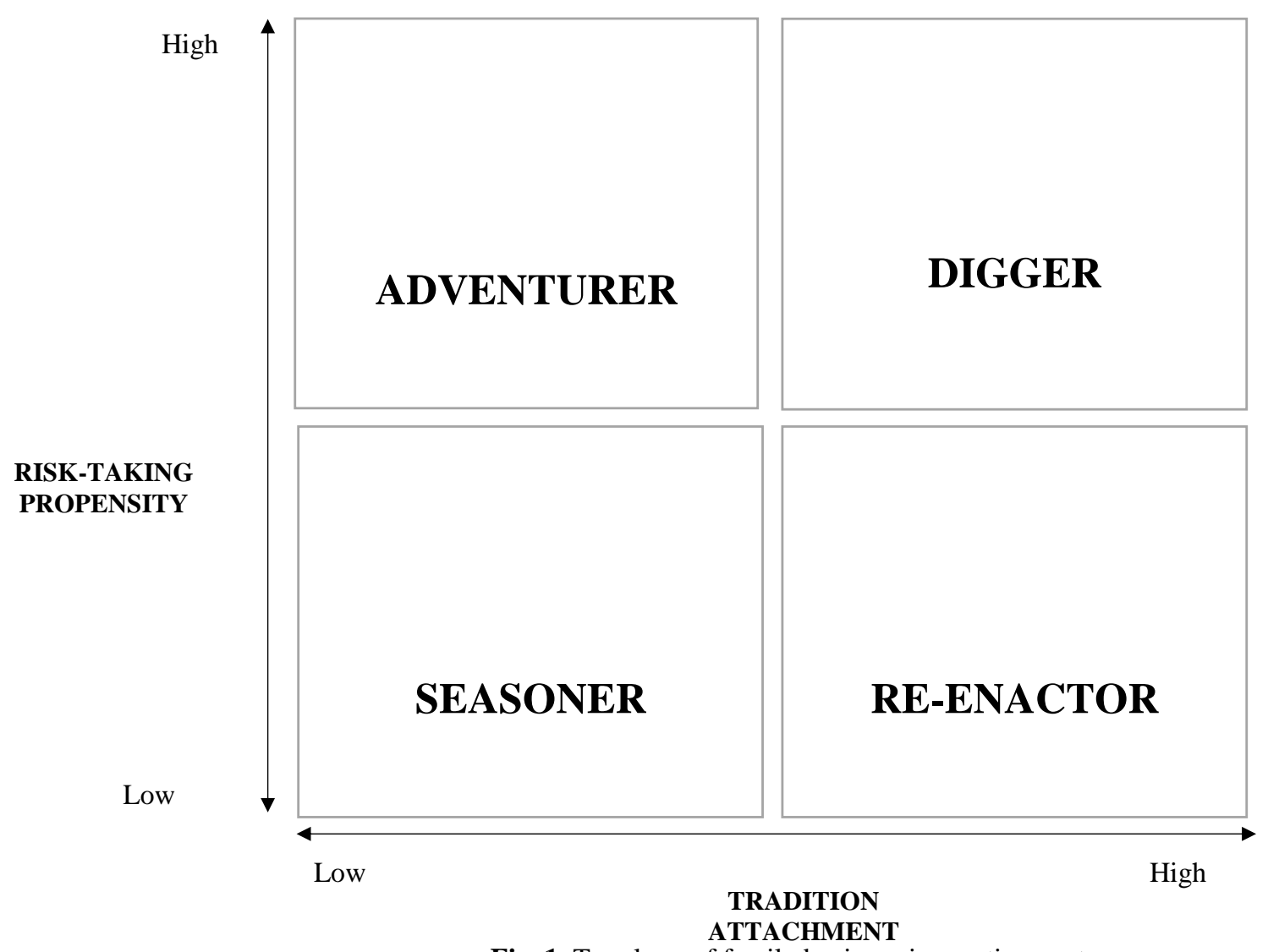

Fig. 1. Typology of family business innovation postures 
Table 1

Data collection

\begin{tabular}{lc}
\hline Data type & Body of evidence \\
\hline & Primary data \\
\hline Interviews (Consultants) & $\mathbf{3 0}$ hours \\
\hline Observations (Consultants) & $\mathbf{1 0}$ hours \\
\hline Interviews (Successors) & $\mathbf{4}$ hours \\
\hline & Secondary data \\
\hline Press articles (Illustrative cases) & $\mathbf{1 5 0}$ pages \\
\hline Video (Illustrative cases) & $\mathbf{1 0}$ hours \\
\hline Presentations (Consultants) & $\mathbf{4 0}$ hours \\
\hline Books (Consultants, illustrative cases) & $\mathbf{\# 2 , ~ \# 3}$ \\
\hline Websites (Consultants, illustrative cases) & $\mathbf{\# 2 , ~ \# 4 ~}$ \\
\hline
\end{tabular}


Table 2

Illustrative examples of fit between family business innovation posture and family system dimensions

\begin{tabular}{|c|c|c|c|c|}
\hline \multicolumn{3}{|c|}{ Family Business Innovation Posture } & \multicolumn{2}{|c|}{ Family System Dimensions } \\
\hline Typology & Risk-taking propensity & Tradition attachment & Family goal diversity & Family cohesion \\
\hline $\begin{array}{l}\text { Seasoner } \\
\qquad \begin{array}{l}\text { Lllustrative case: } \\
\text { Luray Caverns }\end{array} \\
\text { "The family's small empire has } \\
\text { grown over the years to include } \\
\text { a rope course, a hedge maze } \\
\text { and a museum of classic cars, } \\
\text { plus two motels and a golf } \\
\text { course. These days, a ticket to } \\
\text { tour the caverns also includes } \\
\text { access to the adjacent toy and } \\
\text { antique car museums." } \\
\text { (Washington Post, 2012) }\end{array}$ & $\begin{array}{l}\text { Low } \\
\text { "The family has invested more } \\
\text { deeply in bolstering its main } \\
\text { attraction and keeping the visitors } \\
\text { coming [...] trying to cut costs } \\
\text { [rather than bearing the risk of } \\
\text { further investments], working with } \\
\text { vendors to develop self-guided tours" } \\
\text { (The Washington Post, 2013) }\end{array}$ & $\begin{array}{l}\text { Low } \\
\text { "Graves promoted science } \\
\text { rather than the mysteries of the } \\
\text { underworld and created a corps } \\
\text { of professional guides who } \\
\text { moved the Caverns experience } \\
\text { away from the carnival theatrics } \\
\text { of an earlier generation." } \\
\text { (Video) }\end{array}$ & $\begin{array}{l}\text { Low } \\
\text { "Elizabeth and Katherine both } \\
\text { said in depositions that they were } \\
\text { encouraged to follow their } \\
\text { passions and pursue careers away } \\
\text { from the Caverns in part because } \\
\text { of the knowledge that the } \\
\text { Caverns' stock - their inheritance } \\
\text { - would be available in their } \\
\text { retirement". (The Washington } \\
\text { Post, 2013) }\end{array}$ & \begin{tabular}{l}
\multicolumn{1}{c}{ Low } \\
"Ted Graves died in 2010 at 87. \\
His wife, Rebecca Graves, died \\
two years later. Their six \\
surviving children have been in \\
near-constant litigation for most \\
of the past 10 years, threatening a \\
chain of ownership that now \\
extends four generations." (The \\
Washington Post, 2013)
\end{tabular} \\
\hline $\begin{array}{l}\text { Re-enactor } \\
\qquad \begin{array}{l}\text { Illustrative case: } \\
\text { Smarties }\end{array} \\
\text { "They have also recently } \\
\text { launched a new product, the } \\
\text { Smarties 'n Creme. They are } \\
\text { about the size of a quarter with } \\
\text { a combination of cream and } \\
\text { fruit.". (Tharawat magazine, } \\
\text { 2015) }\end{array}$ & $\begin{array}{l}\text { Low } \\
\text { “"There was a time when we were } \\
\text { approached by numerous other states } \\
\text { to make the move out of New Jersey, } \\
\text { because the cost of doing business in } \\
\text { the state - well, it's not one of the } \\
\text { friendlier states for manufacturing' } \\
\text { said Jessica Dee Sawyer, } \\
\text { granddaughter and vice president, } \\
\text { 'But we decided to [stay] here'." } \\
\text { (Tharawat Magazine, 2015) }\end{array}$ & $\begin{array}{l}\text { High } \\
\text { "The family company would go } \\
\text { on to become a giant in the } \\
\text { candy world, but never strayed } \\
\text { far from its roots." (Tharawat } \\
\text { Magazine, 2015) } \\
\text { "It's an old-fashioned business } \\
\text { structure, and it's fascinating to } \\
\text { hear a young, smart generation } \\
\text { so keen to preserve it! The } \\
\text { young Dee women describe } \\
\text { being born with the business in } \\
\text { their blood in a manner as } \\
\text { nostalgic as the company's } \\
\text { products themselves." (MBS } \\
\text { Group Website) }\end{array}$ & \begin{tabular}{l}
\multicolumn{1}{c}{ Low } \\
"The three women all agreed that \\
their goal was to keep the \\
company in the family. 'I hope \\
for my daughter's sake, that the \\
business is here for her' Ms. \\
Sawyer said. Liz Dee quickly \\
added, 'If the next few \\
generations are like the last three, \\
I think we'll all be very pleased'." \\
(New York Times, 2015)
\end{tabular} & $\begin{array}{l}\text { High } \\
\text { "The trio got their start playing } \\
\text { hide-and-seek and rollerblading } \\
\text { on the factory floor. Many } \\
\text { workers [...] still refer to them as } \\
\text { 'the girls'." (CNN, 2015) }\end{array}$ \\
\hline
\end{tabular}




\begin{tabular}{|c|c|c|c|c|}
\hline $\begin{array}{l}\text { Digger } \\
\qquad \begin{array}{l}\text { Illustrative case: } \\
\text { Beretta }\end{array} \\
\text { "Today, in parallel with their } \\
\text { modern products, they still } \\
\text { produce a range of handmade } \\
\text { guns (snatched up by } \\
\text { collectors), which are symbols } \\
\text { of, and testify to, Beretta's } \\
\text { history.” (The Family } \\
\text { Business: Its } \\
\text { Governance for Sustainability, } \\
\text { 2016) }\end{array}$ & $\begin{array}{l}\text { High } \\
\text { "During the five centuries of the } \\
\text { company's existence, at least ten } \\
\text { major changes in manufacturing } \\
\text { technology of their products have } \\
\text { been absorbed and applied in their } \\
\text { workshops. In the 1980's, for } \\
\text { instance, Beretta installed an up-to- } \\
\text { date computerized system for } \\
\text { designing and manufacturing } \\
\text { pistols." (The Family Business: Its } \\
\text { Governance for Sustainability, 2016) }\end{array}$ & $\begin{array}{l}\text { High } \\
\text { "We always need to understand } \\
\text { and respect the tradition, } \\
\text { because everything is based on } \\
\text { our past. But at the same time } \\
\text { each generation has to bring } \\
\text { new concepts in product and } \\
\text { manufacturing. Me and my } \\
\text { brother we are the fifteenth } \\
\text { generation and we need to bring } \\
\text { what is actual." (Forbes, 2014) }\end{array}$ & \begin{tabular}{l}
\multicolumn{1}{c}{ High } \\
"At the beginning of my activity, \\
my uncle brought me to the luxury \\
rifle department, handmade. He \\
explained that the sector would \\
not have survived beyond \\
employees' retirement since \\
young employees, like me, would \\
not have continued such artisanal \\
activity. However, I was so \\
fascinated by those pieces of art \\
that I insisted with my father that \\
the department continued and \\
young employees were coached \\
by seniors with experience." \\
(Franco Gussalli Beretta, \\
Repubblica, 2015)
\end{tabular} & $\begin{array}{l}\text { High } \\
\text { "The family was always very } \\
\text { close, for work and also for the } \\
\text { financial side, for the decisions. } \\
\text { No one person is more important } \\
\text { than the family, but only one } \\
\text { person must run it." (Franco } \\
\text { Gussalli Beretta, Repubblica, } \\
\text { 2015) } \\
\text { "The family always goes together, } \\
\text { this means we work very hard } \\
\text { together. This is important } \\
\text { because the family together is } \\
\text { much stronger than one person." } \\
\text { (Forbes, 2014) }\end{array}$ \\
\hline $\begin{array}{l}\text { Adventurer } \\
\qquad \begin{array}{l}\text { Illustrative case: } \\
\text { Esselunga }\end{array} \\
\text { "After being the first in Italy to } \\
\text { introduce the barcode reader at } \\
\text { the checkout in 1980, Esselunga, } \\
\text { in the year of its 60th } \\
\text { anniversary, continues to } \\
\text { reaffirm its identity as an } \\
\text { innovative operator and [...], } \\
\text { will allow paying grocery } \\
\text { shopping through your } \\
\text { smartphone." (L'Eco di } \\
\text { Bergamo, 2017) }\end{array}$ & \begin{tabular}{l}
\multicolumn{1}{c}{ High } \\
"Esselunga collaborated with Barilla \\
to develop Legumotti. The two \\
companies together identified the \\
cereal and legumes sector as a fast \\
growing but not adequately overseen \\
market. They decided to collaborate \\
with a team of university professors \\
adopting the design thinking \\
methodology. [...] This approach \\
allowed them to develop 45 \\
prototypes and commercialize a new \\
product in only one year." (Sole 24 \\
Ore, 2017)
\end{tabular} & \begin{tabular}{l}
\multicolumn{1}{c}{ Low } \\
New openings, a logistics \\
center, the fourth for the \\
company. But even lesser \\
traditional territories' \\
challenges, such as ecommerce, \\
become one of the pillars of \\
future growth that makes \\
Esselunga the only retail group \\
in Italy, after having been a \\
pioneer, to embark on home \\
delivery service in a structured \\
manner [regardless of the family \\
tradition]." (Corriere della Sera, \\
2017)
\end{tabular} & \begin{tabular}{l}
\multicolumn{1}{c}{ High } \\
"While the heirs - Bernardo's \\
wife Giuliana Albera, his \\
daughter Marina Sylvia, and \\
siblings Violetta and Giuseppe - \\
still seek to agree on the legacy of \\
the largest private group of large \\
retailers, the Esselunga machine \\
continues to churn full swing." \\
(Corriere della Sera, Newspaper, \\
2017)
\end{tabular} & \begin{tabular}{l}
\multicolumn{1}{c}{ Low } \\
"Before dying, the entrepreneur \\
divided all his properties with \\
painstaking accuracy (the same \\
with which he took care of his \\
supermarkets) in order to avoid \\
further disputes and claims \\
'allowing all' to 'live in peace in \\
their position'. Not an easy task \\
because the same inheritance is \\
proof of how family divisions are \\
still deep and positions are \\
distant." (La Repubblica, 2016)
\end{tabular} \\
\hline
\end{tabular}

